muon formation which gave the largest partial correlation coefficient.

This work demanded the meticulous analysis of a great amount of numerical data, at which Duperier was exceedingly expert. To facilitate this work he pioneered the use of business accounting machines for the analysis of cosmic-ray data. Later he refined his analytical method by introducing a three-term regression formula, and by this means obtained some indication-but no final proof - of the effect on the cosmic-ray intensity at sea-level of the pion decay in the upper atmosphere. This last work was carried out at Birkbeck College, where he moved soon after the War. In 1945 he gave the Guthrie Lecture to the Physical Society of London on the "Time Variations of Cosmic Rays".

Duperier was well known to cosmic-ray workers all over the world and regularly attended the biennial meetings of the International Cosmic Ray Conference, under the auspices of the International Union of Pure and Applied Physics, which has met since the War in Poland, India, France, Mexico and Italy. He will be greatly missed at the next meeting, planned for this summer in Moscow.

In 1951 Duperier returnod to Spain, where he resumed his professorship in the Faculty of Science in the University of Madrid. The loss to his country of the most distinguished Spanish atomic physicist of his generation is indeed great. He was awarded posthumously the Juan March Foundation prize of 500,000 pesetas for his outstanding scientific work.

Throughout Duperier's thirteen years in England, I was in close touch with his work, and came greatly to admire him not only as a scientist but also as a man of unbending rectitude of character. It is thus both as a fine scientist and as a close personal friend that I mourn his death. P. M. S. BLACKETT

\section{Prof. Pierre Fauvel}

Puerre Fauvel, professor in the University of Angers, who died on December 12, was one of the greatest systematic zoologists. A specialist on Polychaeta, a group with which his name will for ever be associated, Fauvel was supreme in his field. No one who preceded him and none of his contemporaries approached the brilliance of his systematic interpretation.

Fauvel was born at Cherbourg on October 8, 1866. Throughout the greater part of his professional life he was on the staff at the Catholic University of Angers, as professor of zoology for fifty-three years, with a term of office as dean of the Faculty of Science from 1942 until 1947.

In the early stages of his career, 1894-1909, Fauvel worked on human physiology, publishing papers on digestion and uric acid secretion, and on general marine biology. In the latter field he carried out research on the larval development of Arenicola, on the circulation in Amphictenidae, on otocysts and on nephridia. For his doctorate of science he published observations made on the Ampharetidae. During 1910-20, however, the trend towards systematics becomes more apparent, and Fauvel's first major work in this field was on collections of polychaetes made in the Mediterranean and Atlantic during cruises of l'Hirondelle and Princesse Alice, under the direction of Prince Albert of Monaco. There followed papers on collections from the Falkland Islands, Australia, West Africa and Madagascar in this period, and all indicated that a new and brilliant figure had arisen.

With the publication in 1923 and 1927 of his two volumes in the "Faune de France" series, Fauvel's position as the outstanding authority on polychaetes was established. He provided in these works a practical method of identifying almost 900 species, his sedulous preparation of keys, in particular, being of the greatest value. In the genera Harmothoë, Nereis and Serpula, numerous species, previously a jumbled assortment of specimens and populations, were reduced to a series of well-defined natural groups as clearly delineated as available knowledge allowed. For those most difficult of families, the Phyllodocidae and Syllidae, his consideration of the species concept brought order out of confusion. This same ability to define species and clarify taxonomic problems is evident in all the families, so that these volumes have been in continual use in practical marine courses throughout the world since publication, and will probably not be replaced, even by local faunal publications, for years to come. Marine ecologists and physiologists everywhere praise their value and no specialist would consider approaching a problem concerning polychaetes before first noting what Fauvel had to say. In addition, these two works represent models of how the perfect faunal study should be presented, and their extension to other groups (and other areas for Polychaeta) is of paramount importance.

In 1932 Fauvel's work on the polychaetes from the Indian Museum in Calcutta was published, and this also is an invaluable guide to the student and specialist. It was the first comprehensive publication on polychaetes from subtropical and tropical waters, and has been the basis of all later diagnoses of the Indo-Pacific fauna.

Through experience with populations from widely separated regions, Fauvel was able to demonstrate the cosmopolitan nature of many species and the unique endemic elements in particular areas. He was the first to recognize the occurrence in Europe of Mercierella enigmatica as an invasion, possibly from India, of a species capable of breeding in waters of low salinity. Since then, repeated records of this polychaete from harbours in western Europe have indicated how damaging the effects of its growth might be.

Honours, richly deserved, were paid to Fauvel by his native France; they included: Chevalier de la Légion d'honneur; Lauréat de l'Institut, Prix Savigny de l'Académie des Sciences; Membre de la Société Zoologique de France; Membre Correspondant du Muséum d'Histoire naturelle de Paris. It is indeed with pride that systematic zoologists can point to the career of Pierre Fauvel, for he always upheld the finest traditions of learning in pursuing his chosen subject to the utmost of his ability, and he gave to zoology some of the finest products of scholarship published during his life-time.

\section{Norman Tebrle}

\section{Dr. Herbert Hunter}

Dr. Herbert Hunter died on February 21 at Meldreth, near Cambridge, at the age of seventy-six, after a long and productive working life, during which he had made outstanding contributions to plant breeding, to agriculture and to the malting and brewing industries. He will always be remembered for his activities in these fields, and also as a dedicated research worker and student of his subject who kept his interest in his work up to the time of his death. 
Hunter graduated from the University of Leeds, of which he was a D.Sc., and started his researches into barley breeding in the early 1900's. This early work was conducted in Ireland, where he was head of the Plant Breeding Division, Department of Agriculture, Dublin, while he also became the first director of the Stormont Plant Breeding Station in Northern Ireland. Later, during 1936-46, Hunter was director of the Cambridge University Plant Breeding Institute. When in Ireland he bred the hybrid barley variety, Spratt-Archer, which was afterwards to make his name when it became one of the most successful varieties of cereals ever bred for Great Britain. It was introduced into cultivation in 1914, and has only been superseded as a standard malting barley in recent years. Hunter went to Cambridge in 1924, and he there bred two more varieties of barley-Earl and Camton-and a winter oat variety named Picton. All these varieties found a place in British agriculture and received official recommendation for farmers. Hunter's contributions gave him an established position with Sir Rowland Biffen and Dr. E. S. Beaven as successful pioneer plant breeders exploiting the new genetic knowledge.

This work ensured the recognition of Hunter's name nationally and internationally, but ho also acquired a great reputation as a writer. He started contributing scientific papers and articles as early as 1908 , and maintained a steady output throughout his life. He was an easy, lucid and fluent writer, and found an outlet for his talent in writing books, of which he had a number of successes to his credit. $\mathrm{He}$ wrote a standard work on oats, and one on barley in the 1920's, while in 1931 he edited a new edition of Baillière's "Encyclopædia of Agriculture" (with H. Martin Leake), while his most recent contributions were "Crop Varieties" (1954) and "The Barley Crop" (1956).

One of Hunter's great interests was the work of the National Institute of Agricultural Botany, to which he gave most valued service as a member of Council for twenty-one years, as acting director during the Second World War, and as chairman of Council for three years. For his services he was elected a vice-president of Council, a signal recognition of the way in which he guided the Institute's work and activities and established its present important relationships with agriculturists and commercial interests in the seed trade. Hunter's great tact, wisdom and kindliness were all instrumental in accomplishing this work so successfully, and those who worked under him in both Institutes which he directed were grateful for the experience.

In 1911 Herbert Hunter married Rosa Wise, of Springfield, Ohio. She died in 1945, and Hunter married in 1951 Mrs. Blanche Metters, widow of J. D. Metters. He is survived by his widow and two daughters of his first marriage. G. D. H. BELL

\section{Dr. Alexander M. Cockburn}

ON February 28 Dr. Alexander Murray Cockburn, senior lecturer in geology in the University of Edinburgh, died at the age of fifty-seven.

Dr. Cockburn graduated with first-class honours in geology at Edinburgh in 1924. After a season with the Geological Survey of Canada, and some time spent in studying volcanic phenomena in Hawaii, he returned to his native city to take up postgraduate research as a Falconer Fellow of the University. In
1927, with John Mathieson, Dr. Cockburn carried out the first detailed topographic survey of the St. Kilda group of islends, and in the following year he completed a geological study of these islands, which was published in the Transactions of the Royal Society of Edinburgh in 1935, and remains a distinguished contribution to our knowledge of Scottish geology.

Dr. Cockburn was awarded the degree of Ph.D. in 1929, and was elected a Fellow of the Royal Society of Edinburgh in 1935. He began his long service as a member of the staff of the University of Edinburgh in 1931, and passed successively through the positions of assistant and curator of the museum, lecturer, and senior lecturer. In 1942, he took over from Prof. T. J. Jehu the courses in stratigraphy, and since then he was responsible for the formal stratigraphy courses in the Department. However, he never lost his early interest in vulcanology, and he made a comprehensive study of the volcanic rocks of the Pentland Hills. It is most unfortunate that his early death should have prevented him from publishing more than a small part of this work.

From 1951 onwards Dr. Cockburn acted as director of studies in pure science, and he was a member of the Senatus Academicus of the University of Edinburgh from 1956. A prominent Fellow of the Edinburgh Geological Society, he served as honorary secretary during 1939-44, and was elected president in 1958 .

These few details of Dr. Cockburn's career can reveal little of the enormous debt which is owed to him by his Department and by all who have been associated with it. $\mathrm{He}$ combined a complete and unselfish loyalty to his subject and his Department with a deep and stimulating understanding of the personal problems of his students. He was a most able and conscientious teacher, both in the lecture room and in the field, and he carried a considerable administrative load. One of his great interests was the geological museum, and to this, and to the care of the Grant Institute building, he devoted a great deal of time and skill. Recently he has played a large part in the planning associated with a new building programme, and in the change from a threeyear to a four-year honours course in geology. All the students who came under his care will remember with gratitude and affection the help and advice which he gave so readily, and his unfailing kindness, wisdom and good humour. All who were fortunate enough to know him feel a tragic sense of personal loss.

F. H. STEWART

\section{Dr. S. Bekku}

BY the death on September 19 last in Tokyo of Dr. S. Bekku, Japan has lost one of her distinguished electrical engineers.

Dr. Bekku was born at Ueno, Tokyo, in 1893, and he graduated in electrical engineering from the Tokyo Imperial University in 1917. After graduation he pursued advanced studies in the Electro-Technical Laboratory on electrical power transmission and high-voltage engineering. It was at this stage that Dr. Bekku had the opportunity of going to the United States and working with the Westinghouse Electric Company under the direction of Dr. C. L. Fortescue. In 1927, Dr. Bekku received the degree of doctor of engineering from the Tokyo Imperial University, and in 1928 he was appointed to a professorship in the Tokyo Institute of Technology. Here he lectured on transmission and high-voltage engin- 